\title{
Rainwater harvesting as an alternative option for sustainable water management of Dhaka city
}

\author{
A. Tabassum, F. Hasan Ovi, M. A. Hanif \& I. Islam \\ Department of Urban and Regional Planning, \\ Bangladesh University of Engineering and Technology (BUET), \\ Bangladesh
}

\begin{abstract}
Despite the advancement of technology in the recent past, the global scenario still remains grim in water supply as not all the inhabitants of the world have access to safe drinking water. Dhaka city is now facing tremendous challenges to fulfil the water demand of its inhabitants. Groundwater table depletion is increasing at an alarming rate. This study mainly focuses on the potential of a rainwater harvesting system in Kazipara area of Dhaka city. The study area has typical characteristics of an unplanned, congested development with a small plot size of Dhaka city. That is why this area has been chosen. Residents of this area face both water crises in dry summer and water logging in monsoon. It has been calculated that the potential of rooftop rainwater harvesting is 4,02,096.34 cubic meter water/year which can meet about a $66 \%$ demand of water for toilet flushing and cleaning purposes used by the residents of Kazipara all year round. If a rainwater harvesting system is used every buildings of the study area then $2,872.12 \mathrm{cum} / \mathrm{hr}$ surface runoff would be reduced during a rainfall event of $15 \mathrm{~mm} / \mathrm{hr}$, which means $61.71 \%$ of surface runoff would be reduced from the current surface runoff. As a consequence, water logging problem can be decreased in Dhaka city.

Keywords: rainwater harvesting, feasibility, potential, willingness to install rainwater harvesting system.
\end{abstract}




\section{Introduction}

Dhaka, the capital of Bangladesh is the $19^{\text {th }}$ mega city in the world with a population of over 14 million [1]. With the rapid growth of the urban population the city is unable to cope with changing situations due to their internal resource constraints and management limitations. Water crisis has become an acute problem faced by the inhabitants of Dhaka city. It is found that the total water demand in Dhaka city is 2,240 million litres per day (MLD) whereas supply is 2,150 (MLD). About 87 percent of this supply comes from groundwater resources and the remaining 13 percent from surface water [2]. For the huge extraction from the underground water source, the ground water table is declining day by day. It has been found that the current groundwater depletion rate is 3.52 meter per year [2]. Such a fast depletion of the water table will result in an intrusion of southern saline water into the groundwater reservoir, depriving this mega city of pure drinking water.

Not only water scarcity but also water logging is an acute problem for the inhabitants of Dhaka city, disrupting traffic movement and creating health, hygiene and environmental problems in the life of city dwellers. Between September 11th to 16th, 2004 the heaviest ever rainfall $(341 \mathrm{~mm})$ occurred in Dhaka City and its devastating impact paralyzed city life. A report by Dhaka's Water and Sewerage Authority (DWASA) indicates that water logging during September affected 250 schools and 681 garment factories in Dhaka city and damaged roads and telephone lines extensively. On May 22, 2006 the city experienced $38 \mathrm{~mm}$ rainfall in 3 hours, resulting in a huge water logging problem [3].

Rainwater harvesting can be an alternative source to reduce water scarcity as well as the water logging problem of Dhaka city. Rainwater harvesting is a simple and easy technique used for collecting and storing rainwater for human use. For centuries, the world has relied upon rainwater harvesting as a source of water for household and agricultural purposes. It empowers individual and communities to manage their water and use it in the dry season as well as at times of their need. There are multiple benefits of rainwater harvesting, such as the improvement of the quantity and quality of water, mitigating the effect of drought and recharging the groundwater table, reducing the soil erosion as surface runoff decreases and ensuring a sustainable water management system [4]. It is the "least cost" form of water supply, largely in comparison with the high cost of alternative sources. Although the potentiality of rainwater harvesting is tremendous many people are not aware of it. They are suffering from a severe water supply problem and want a permanent solution to this problem. This study mainly focuses on the potentiality of rainwater harvesting in a densely built up area like Kazipara area of Mirpur. Water scarcity is a severe problem in dry season in this area. Every year there are riots and protests because of the need for water. Moreover, water logging in monsoon season has a huge effect on the daily activities of the inhabitants of Kazipara area of Mirpur. Rainwater harvesting can be an alternative source to meet the increasing demand for water as well as reducing the water logging problem. 


\section{Concept of rainwater harvesting}

Rainwater is a free source of nearly pure water and rainwater harvesting refers to the collection and storage of rainwater and other activities aimed at harvesting surface and ground water. It also includes the prevention of loss through evaporation and seepage and all other hydrological and engineering interventions, aimed at conservation and efficient utilization of the limited water endowment of physiographic unit such as a watershed [5]. Construction of RWH systems is simple and local people can easily be trained to build these themselves. This reduces costs and encourages more participation, ownership and sustainability at a community level.

\section{Methodology of the study}

Rainfall is the most crucial and unpredictable variable to calculate the potential of rainwater harvesting of an area. Rainfall data from 1950-2005 for Dhaka division has been collected from the Bangladesh Meteorological Department (BMD). From the analysis it was found that the average annual rainfall for Dhaka division is about 2,100 $\mathrm{mm}$ [6].

In this study, a roof top rainwater harvesting system is considered only. It is necessary to calculate the area of rooftop in order to identify the potential of rainwater harvesting in each building. To calculate the roof top area GIS database has been used. The total number of structures in the Kazipara area of Mirpur has been counted; totalling about 2,207. From this population, a sample size has been determined, which is 327 structures at 95\% confidence level and $5 \%$ confidence interval [7]. It is found that the size of the rainwater harvesting tank depends on the demand for water in each structure and availability of the catchment area. Thus the installation of a rainwater harvesting system is much likely related with size of the catchment area. Considering this factor, stratified sampling is used to categorize the size of the rooftop area. The categories are: less than 67 sq. meters, between 67-133 sq. meters, between 133-200 sq. meters and more than 200 sq. meters. After stratified sampling, the sample size for each category is $124,128,49$ and 26.

A questionnaire survey method has been used to identify the general information of local people, water consumption, water use, etc.

\section{Potentiality of rainwater harvesting in the Kazipara area}

Urban areas are typically characterized by a concentrated demand for water because of high population density and varied uses of water. As a result, the water supply problem becomes acute. In this circumstance, there is a need for alternative water supply sources and thus rainwater harvesting comes to attention.

The Kazipara area of Mirpur is one of the densely populated areas of Dhaka city. A water scarcity problem in dry season is a common scenario every year in this area. The ground water level is declining every year in Kazipara and it 
becomes difficult for the Dhaka Water Supply and Sewerage Authority (DWASA) to provide the required amount of water to the local people. The Kazipara area in 2008 ground water level was 160 feet but in 2012 the level was 180 feet. So in four years 20 feet has been declined [2]. Among various reasons, groundwater withdrawal from the aquifer is the major reason. Rapid urbanization including construction of roads, buildings, other engineering structures, flood protection dams, and embankments are continuously hindering the natural groundwater recharges from rainfall and perennial water sources existing in and around the city. Illegal encroachment also causes the ground water level to fall off.

Not only water scarcity but also water logging during the monsoon season creates huge inconveniences for the inhabitants of the Kazipara area. Through rainwater harvesting system, the increased demand of water might be partially fulfilled and will also reduce water logging problems of the Kazipara area.

\subsection{Rainfall data}

Potentiality of rainwater of an area varies due to the change of rainfall pattern, quantity and quality. To calculate the potentiality of rainwater harvesting of a given area, reliable rainfall data is required. A total of 228 rainfall stations and 54 automatic rainfall recorders surround Bangladesh [8]. Those rainfall stations give rainfall data every day. There are also 34 BMD stations which record rainfall data every day [8]. Approximately 70 per cent of the annual rainfall occurs during the monsoon period. Rainfall data from 1950-2005 has been analyzed. From the analysis it was found that the average annual rainfall for the Dhaka division is about 2,100 $\mathrm{mm}$ [6]. This rainfall data is taken as the annual rainfall of the study area for this research.

\subsection{Catchment area}

The roof of a dwelling is the common form of rainwater catchment. There are 2,207 structures in the study area. The majority of the structures have medium sized rooftop areas with a range of 47-112 sq. meters. So it can be said that in the Kazipara area, the buildings are a comparatively small size.

\subsection{Runoff co-efficient}

Runoff coefficient is another important issue to determine the potential of rainwater harvesting. It is the factor which accounts for the fact that all the rainfall falling on a catchment cannot be collected. Some rainfall will be lost from catchment by evaporation and retention on the surface itself. It decides how much rain water can be harvested [9]. The runoff coefficient differs according to the different surface areas. In this study only rooftop catchment areas have been considered for calculating the runoff. For the roof tops of the Kazipara area the runoff coefficient is considered as 0.8 . The runoff coefficient for various types of surface is given in table 1 
Table 1: $\quad$ Runoff coefficient for various surfaces.

\begin{tabular}{|l|c|}
\hline \multicolumn{1}{|c|}{ Type of surface } & Coefficient \\
\hline Roof catchment & \\
\hline - Tiles & $0.8-0.9$ \\
\hline - Corrugated metal sheets & $0.7-0.9$ \\
\hline Ground surface coverings & $0.6-0.8$ \\
\hline - Concrete & $0.5-0.6$ \\
\hline - Brick pavement & \\
\hline Untreated ground catchments & $0.0-0.3$ \\
\hline - Soil on slopes less than 10 percent & $0.2-0.5$ \\
\hline - $\quad$ Rocky natural catchments & \\
\hline
\end{tabular}

\subsection{Calculation of potential of rainwater harvesting}

To calculate the potential of rainwater harvesting at Kazipara at first each building roof top area has been calculated from secondary source and surface runoff has been calculated. Then catchment areas are multiplied by the average annual rainfall and runoff coefficient. The potential of rainwater harvesting would be

Potential of rainwater harvesting in each building $=A * R * C[9]$

$\mathrm{A}=$ Catchment area of each building (Area of roof top).

$\mathrm{R}=$ Average Annual Rainfall of Dhaka city $(2,100 \mathrm{~mm})$.

$\mathrm{C}=$ Coefficient (0.8).

Example

Rainwater harvesting potential for a building having a roof top area of 127.53 sq. $\mathrm{m}$ can be calculated as follows:

$\mathrm{A}=127.53$ sq. $\mathrm{m}$.

$\mathrm{R}=2,100 \mathrm{~mm}$.

$\mathrm{C}=0.8$.

So, the potential of rainwater harvesting of that building $=127.53 * 2,100 * 0.8$ $=2,14,340$ litre/year (approximately).

\subsection{Rainwater harvesting potential for 327 surveyed buildings}

Different values for the potential of rainwater harvesting have been found for different buildings with the variation of catchment area. It is directly related with the size of catchment area. The potential of rainwater harvesting has been 
calculated for every 327 buildings using the equation. The total potential of the surveyed buildings of Kazipara is 62,753,712 litres of water. The total and average rainwater harvesting potential of those surveyed according to the roof top size is given in the Table 2 .

Table 2: $\quad$ Total rainwater harvesting potential for 327 surveyed buildings.

\begin{tabular}{|c|c|c|c|c|c|}
\hline $\begin{array}{l}\text { Roof top } \\
\text { area (sq. } \\
\text { meter) }\end{array}$ & $\begin{array}{c}\text { Total roof } \\
\text { area } \\
\text { (sq. m.) }\end{array}$ & Coefficient & $\begin{array}{c}\text { Rainfall } \\
\text { (mm) }\end{array}$ & $\begin{array}{c}\text { Total } \\
\text { rainwater } \\
\text { harvesting } \\
\text { potential } \\
\text { (litre) }\end{array}$ & $\begin{array}{c}\text { Average } \\
\text { rainwater } \\
\text { harvesting } \\
\text { potential } \\
\text { (litre) }\end{array}$ \\
\hline $\begin{array}{l}\text { Less than } \\
67 \text { sq. m }\end{array}$ & $6,860.52$ & \multirow{4}{*}{0.8} & \multirow{4}{*}{2,100} & $11,525,673.6$ & $92,948.98$ \\
\hline $\begin{array}{c}\text { Between } \\
67-133 \text { sq. } \\
\text { m } \\
\end{array}$ & $14,402.72$ & & & $24,196,569.6$ & $189,035.70$ \\
\hline $\begin{array}{c}\text { Between } \\
133-200 \\
\text { sq. m } \\
\end{array}$ & $8,672.61$ & & & $14,569,984.8$ & $297,346.63$ \\
\hline $\begin{array}{l}\text { More than } \\
200 \text { sq. m }\end{array}$ & $7,417.55$ & & & $12,461,484.0$ & $479,287.85$ \\
\hline Total & $37,353.4$ & & & $62,753,712.0$ & $191,907.36$ \\
\hline
\end{tabular}

From table 2 it is observed that with the increase of catchment area, rainwater harvesting potential also increases. So, large plot sizes have more privilege to harvest more rainwater.

\subsection{Rainwater harvesting potential of total Kazipara area}

There are total 2207 buildings in Kazipara. If only the roof top area of all buildings have been used as catchment area, then the total catchment area is 239,343.1 sq. meters.

Total rainwater harvesting potential would be, $\mathrm{A}=239,343.1$ sq. $\mathrm{m}$.

$\mathrm{R}=2,100 \mathrm{~mm}$.

$\mathrm{C}=0.8$.

Total rainwater harvesting potential of Kazipara $=239,343.1 * 0.8 * 2,100$

$$
\begin{gathered}
=402,096,341.4 \text { litre per year } \\
=402,096.34 \mathrm{~m}^{3} \text { water/year. }
\end{gathered}
$$

\subsection{Rainwater harvesting to reduce the water scarcity problem at Kazipara}

Water is essential for all living creatures. The quantity of water delivered and used for households is an important aspect of domestic water supplies, which 
influences hygiene and therefore public health. The total consumption of water per person is greatly influenced by some factors:

- Availability of water;

- $\quad$ Distance to the water source;

- $\quad$ Price of the water;

- Quality of the water;

- Climatic conditions etc.

In Dhaka city there is no such standard as to how much water is required by a person. That is why the South Asian standard has been chosen because of similar characteristics in water consumption pattern.

Table 3: Water requirement for different purposes according to the Center for Science and Environment (CSE).

\begin{tabular}{|c|c|c|}
\hline Use & $\begin{array}{c}\text { Consumption } \\
\text { (litres/day/person) }\end{array}$ & $\begin{array}{c}\text { Percentage } \\
\text { consumption }\end{array}$ \\
\hline Drinking & 5 litres & $3.70 \%$ \\
\hline Cooking & 5 litres & $3.70 \%$ \\
\hline $\begin{array}{c}\text { Bathing (including } \\
\text { ablution) }\end{array}$ & 55 litres & $40.74 \%$ \\
\hline Washing clothes & 20 litres & $14.81 \%$ \\
\hline Washing utensils & 10 litres & $7.41 \%$ \\
\hline Cleaning the house & 10 litres & $7.41 \%$ \\
\hline Flushing of latrines & 30 litres & $22.22 \%$ \\
\hline Total for urban areas & 135 litres/person/day & $100.00 \%$ \\
\hline
\end{tabular}

Rainwater harvesting can be an alternative source of domestic water supply system. This system can be recommended in areas where rainfall is adequate and space is available for the storing of rainwater and using it later for non drinking purposes. If the harvested water can be used for toilet flushing and cleaning the house purposes then $30 \%$ of water can be saved from the conventional piped water supply system.

Suppose total water consumption is $1,10,000$ litres per month in a building then

Water use in toilet flush $=1,10,000 * 22 \%$ litre

$$
=24,200 \text { litre per month. }
$$

Water use in cleaning purpose $=1,10,000 * 8 \%$

$$
=8,800 \text { litre per month. }
$$

Total water consumption for these two purpose $=(24,200+8,800)=33,000$ litres per month.

The total population of the study area is 41,395 [10]. So, the total demand for water per year for toilet flushing and cleaning purposes of the study area is 
$40 * 41,395 * 365=60,43,67,000$ litres per year or $6,04,367$ cubic meters per year.

On the other hand, the potential of rainwater harvesting in the Kazipara area is $4,02,096$ cubic meter water per year.

Through rainwater harvesting, a $66.53 \%$ demand of water for toilet flushing and cleaning purpose can be served. So, this will definitely reduce the pressure on DWASA and also partially solve the water scarcity problem. It is also found that through harvested rainwater, $20 \%$ of the total water demand can be fulfilled.

\subsection{Rainwater harvesting to improve storm water management}

Storm water can also be managed through rainwater harvesting. A huge amount of surface runoff is the main cause of water logging problems in an urban area. If surface runoff is greater than the drainage capacity of the area then water cannot pass through the drainage system and water is logged. Rainwater harvesting can be a possible solution of storm water management. Before calculating surface runoff one has to know about rainfall intensity.

\subsection{Rainfall intensity}

The intensity of rainfall is a measure of the amount of rain that falls over time. The intensity of rain is measured in the height of the water layer covering the ground in a period of time. It means that if the rain stays where it falls, it would form a layer of a certain height. To calculate the surface runoff it is very much important to know the rainfall intensity. Intense rainfall of certain volume will cause greater surface runoff than rainfall of same volume with less intensity. For this study, heavy rainfall intensity of $15 \mathrm{~mm} /$ hour has been chosen for surface runoff calculation.

Table 4: $\quad$ Classification of rainfall according to precipitation.

\begin{tabular}{|c|c|}
\hline Type of rain & Precipitation rate \\
\hline Very light rain & Less than $0.25 \mathrm{~mm} / \mathrm{hour}$ \\
\hline Light rain & between $0.25 \mathrm{~mm} /$ hour and $1.0 \mathrm{~mm} / \mathrm{hour}$ \\
\hline Moderate rain & between $1.0 \mathrm{~mm} /$ hour and $4.0 \mathrm{~mm} /$ hour \\
\hline Heavy rain & between $4.0 \mathrm{~mm} /$ hour and $16.0 \mathrm{~mm} / \mathrm{hour}$ \\
\hline Very heavy rain & between $16.0 \mathrm{~mm} /$ hour and $50 \mathrm{~mm} / \mathrm{hour}$ \\
\hline Extreme rain & More than $50.0 \mathrm{~mm} / \mathrm{hour}$ \\
\hline
\end{tabular}

\subsubsection{Surface runoff calculation of the Kazipara area}

To calculate the surface runoff of an area, the following equation is used

$$
\text { Surface runoff }=\mathrm{C}^{*} \mathrm{I}^{*} \mathrm{~A} \quad[9]
$$

$\mathrm{C}=$ Surface runoff coefficient

$\mathrm{I}=$ Intensity of rainfall (in $\mathrm{mm} /$ hour)

$\mathrm{A}=$ Catchment area. 
There are four types of surface in the study area paved road, roof top, bare soil and water body. The total area of different surface type has been collected from Dhaka Metropolitan Development Plan: Detain Area Plan, 2010. At first, the area of roof top, area of paved road and area of water bodies have been calculated from a GIS database. The rest of the study area has been assumed as bare soil and vegetation. Surface runoff for different types of surface has been calculated using the equation. Calculation for different types of surface is given in table 4.

Table 5: $\quad$ Surface runoff of the study area before rainwater harvesting.

\begin{tabular}{|c|c|c|c|c|}
\hline $\begin{array}{l}\text { Type of } \\
\text { surface }\end{array}$ & $\begin{array}{c}\text { Area (A) } \\
\text { (sq.m) }\end{array}$ & $\begin{array}{l}\text { Intensity } \\
\text { (I) (m/hr) }\end{array}$ & Coefficient & $\begin{array}{l}\text { Surface runoff } \\
\text { (cum/hr) }\end{array}$ \\
\hline Road & 46,223 & \multirow{4}{*}{0.015} & 0.8 & 554.68 \\
\hline Roof top & 239,343 & & 0.8 & $2,872.12$ \\
\hline $\begin{array}{l}\text { Water } \\
\text { body }\end{array}$ & 11,466 & & 0.1 & 17.20 \\
\hline Bare soil & 268,984 & & 0.3 & $1,210.43$ \\
\hline \multicolumn{4}{|c|}{ Total } & $4,654.43$ \\
\hline
\end{tabular}

This huge amount of surface runoff is not properly managed and maintained by DWASA and DCC due to the inadequate present capacity of the drainage system. So, water gets logged for a long time in the study area. However, this water logging problem can be reduced using rainwater harvesting system, at least to some extent.

Table 6: Surface runoff of the study area when rooftop rainwater is harvested.

\begin{tabular}{|c|c|c|c|c|}
\hline $\begin{array}{l}\text { Type of } \\
\text { surface }\end{array}$ & $\begin{array}{c}\text { Area (A) } \\
\text { (sq.m) }\end{array}$ & $\begin{array}{l}\text { Intensity } \\
\text { (I) (m/hr) }\end{array}$ & Coefficient & $\begin{array}{c}\text { Surface } \\
\text { runoff } \\
\text { (cum/hr) }\end{array}$ \\
\hline Road & 46,223 & \multirow{4}{*}{0.015} & 0.8 & 554.68 \\
\hline Roof top & 239,343 & & 0.8 & 0 \\
\hline $\begin{array}{l}\text { Water } \\
\text { body }\end{array}$ & 11,466 & & 0.1 & 17.20 \\
\hline Bare soil & 268,984 & & 0.3 & $1,210.43$ \\
\hline \multicolumn{4}{|c|}{ Total } & $1,782.31$ \\
\hline
\end{tabular}

If the RWH system is applied to all the rooftops of the households of the study area, then a huge amount of surface runoff will be reduced considering the present surface runoff. Through the rainwater harvesting system, rainwater 
which pours onto the road surface from rooftops will be stored in tanks and thus there will be less amount of surface runoff which reduces the probability of water logging.

If a rainwater harvesting system is used in every buildings of the study area then $2,872.12 \mathrm{cum} / \mathrm{hr}$ surface runoff would be reduced during a rainfall event of $15 \mathrm{~mm} /$ hour. This means that $61.71 \%$ of surface runoff would be reduced from the current surface runoff. So, there would be a very high probability that, water logging problem would be very much reduced.

\section{Recommendation}

1. The provision of safe drinking water to all the inhabitants of Dhaka city has become a tremendous challenge for the government. An analysis shows that if $60 \%$ of the rainfall from roof top can be harvested in Dhaka city, more than 200 MLD water can be made available for use. So all the buildings should implement a rainwater harvesting system in their premises to reduce the water scarcity problem of Dhaka city.

2. Sensitization and awareness raising of people en masse is very important to promote rainwater harvesting systems in Dhaka city.

3. Private sectors, especially real estate companies, must be engaged in installing rainwater harvesting systems.

\section{Conclusion}

Water management is very crucial for any country of the world. In the case of Dhaka city it is more challengeable because of the huge population. The Kazipara area depicts the typical characteristics of Dhaka city and from the study, it can be seen that the potential of rainwater harvesting is huge. But the majority of the people are not interested in installing the system. To promote rainwater harvesting and utilization as sustainable urban water management, it is important to establish a network involving government and citizens, architects, planners and other professions. Not only a household rainwater harvesting system but also a community rainwater harvesting system should be considered by the government. Unawareness of the concept of rainwater harvesting system makes people uninterested to adopt the system. Detailed information and analysis of this system in different parts of Dhaka city and disseminating the knowledge through workshop seminars and training programmes will convince more people to install the system. Many cities in the world have already taken the initiative to install a rainwater harvesting system in their buildings. But in Bangladesh, the rainwater harvesting system is not very much popular in urban areas. So it is high time to calculate the potential of rainwater harvesting in urban areas like Dhaka city and promote this system among the local people. It should be borne in mind that every single drop of water must be stored and used for mankind. 


\section{References}

[1] World City Information. World Megacities 2011, http://www.cityinfos.com/world-megacities/

[2] Dhaka Water Supply and Sewerage Authority. Annual Report 2010-2011, Dhaka WASA, Dhaka.

[3] Alam, M. and Rabbani, M.G., Vulnerabilities and Responses to Climate Change for Dhaka. Environment and Urbanization, Published by SAGE on behalf of IIED (International Institute for Environment and Development). pp: 81-97, 2007.

[4] UN-HABITAT. Blue Drop Series on Rainwater Harvesting and Utilisation - Book 2: Beneficiaries \& Capacity Building . UN-HABITAT 2005. http://www.unwac.org/new_unwac/pdf/WATSAN_Normative_Pubs/Blue_ Drop_Series_02_-_Capacity_Building.pdf

[5] Vishwanath, S., Rainwater Harvesting in Urban Areas. Bangalore, India http://www.rainwaterclub.org/docs/R.W.H.industries.urban.pdf

[6] Rahman, M. M., and Akter, K. S. Climate Change Pattern in Bangladesh and Impact on Water Cycle (first edition). ITN - BUET Center for Water Supply and Waste Management, Dhaka, Bangladesh 2011.

[7] Creative Research System. Sample Size Calculator 2012 http://www.surveysystem.com/sscalc.htm

[8] Bangladesh Water Development Board, Hydrological Network (SW). BWDB, UNDP, United Nations Department for Development Support and Management Services Project: BGD-88-054 WRIS, 1999.

[9] Center for Science and Environment. A Water Harvesting Manual for Urban areas Case Studies from Delhi. Center for Science and Environment, New Delhi, India 2010.

[10] BBS. Bangladesh Bureau of Statistics. Dhaka, Bangladesh: Planning Division, Ministry of Planning, Government of the People's Republic of Bangladesh 2011. http://www.bbs.gov.bd/WebTestApplication/userfiles /Image/Census2011/DhakaDhaka/Dhaka_C02.pdf 